\title{
NUTRIENTS CYCLING AND ACCUMULATION IN PEARL MILLET AND PAIAGUAS PALISADEGRASS BIOMASS IN DIFFERENT FORAGE SYSTEMS AND SOWING PERIODS
}

\author{
Ciclagem e acúmulo de nutrientes na biomassa do milheto e capim-paiaguás em diferentes sistemas forrageiros e épocas de \\ semeadura
}

Raoni Ribeiro Guedes Fonseca Costa ${ }^{1}$; Kátia Aparecida de Pinho Costa²; Eduardo da Costa Severiano ${ }^{2}$; Charles Barbosa Santos²; Ana Flávia de Souza Rocha ${ }^{1}$; Wender Ferreira de Souza²; Eduardo Valcácer Brandstetter²; Wayron Araújo de Castro ${ }^{3}$

\author{
1.Department of Biology; Universidade Estadual de Goiás Campus Quirinópolis \\ 2 Professor; Graduate Program in Agricultural Sciences/Agronomy; Instituto Federal Goiano Campus Rio Verde; e-mail \\ (eduardo.severiano@ifgoiano.edu.br) \\ 3 Student; Department in Zootecnhy; Goiás Federal Institute (Instituto Federal Goiano - IF Goiano, Campus Rio Verde);
}

Artigo enviado em 22/04/2017, aceito em 06/08/2017 e publicado em 20/12/2017.

\begin{abstract}
The objective of this study was to evaluate nutrient cycling and accumulation in pearl millet and Paiaguas palisadegrass biomass under different forage systems and sowing periods. The experiment followed a randomized block design with a $5 \times 2$ factorial arrangement and three replications, under five forage systems (monocropped pearl millet, monocropped Paiaguas palisadegrass, pearl millet intercropped in rows with Paiaguas palisadegrass, pearl millet intercropped between rows of Paiaguas palisadegrass and pearl millet oversown and intercropped with Paiaguas palisadegrass) and in two sowing periods (February and March). The results showed that Paiaguas palisadegrass monocropped or intercropped in rows or between rows, exhibited the highest nutrient cycling and accumulation in the remaining biomass. Nutrient accumulation the under all of the examined forage systems showed the following decreasing order: $\mathrm{K}>\mathrm{N}>\mathrm{Mg}>\mathrm{Ca}>\mathrm{P}>\mathrm{S}$. Potassium was the nutrient exhibiting the greatest accumulation in the biomass and it exhibited a higher percent decrease with decomposition time. The first sowing period for the forage systems led to higher nutrient cycling and accumulation in the biomass. Intercropped systems through in integrated crop-livestock showed a promising technique to maintain the nutrient cycling and accumulation with sustainability.
\end{abstract}

Keywords: Nutrient concentration, Urochloa brizantha, intercrop, Pennisetum glaucum (L.) R. Br.

Resumo: O estudo foi desenvolvido com objetivo de avaliar a ciclagem e acúmulo de nutrientes na biomassa do milheto e capim-paiaguás em diferentes sistemas forrageiros e épocas de semeadura. O delineamento experimental utilizado foi o de blocos casualizados, em esquema fatorial 5 x 2, com três repetições, sendo cinco sistemas forrageiros: milheto em monocultivo; capim-paiaguás em monocultivo; milheto consorciado com capim-paiaguás na linha; milheto consorciado com capim-paiaguás na entrelinha e milheto consorciado com capim-paiaguás na sobressemeadura e duas épocas de semeadura (fevereiro e março). Os resultados permitiram constatar que o capimpaiaguás em monocultivo e consorciados na linha e entrelinha apresentaram maiores ciclagens e acúmulos de nutrientes na biomassa remanescente. A ordem decrescente de acúmulo dos nutrientes da biomassa em todos os sistemas forrageiros foi: $\mathrm{K}>\mathrm{N}>\mathrm{Mg}>\mathrm{Ca}>\mathrm{P}>\mathrm{S}$. O potássio foi o nutriente mais acumulado na biomassa, sendo também o que apresentou maior redução percentual com o tempo de decomposição. A primeira época de semeadura dos sistemas forrageiros proporcionou maiores ciclagem e acúmulo de nutrientes na biomassa.

Palavras-chave: Concentração de nutrientes, Urochloa brizantha, consórcio, Pennisetum glaucum (L.) R. Br.

\section{INTRODUCTION}

The use of cover crops under a no-tillage system (NTS) is aimed at providing protection for the soil surface against the direct impact of raindrops, reducing the risk of erosion and allowing greater particle aggregation. Additionally, cover crops have the ability to absorb nutrients in subsurface layers and subsequently release them in surface layers after decomposition and mineralization of the residues. Thus, cover crops harbor considerable nutrient reserves for the growth and development of the subsequent crop, contributing to a decrease in costs and efficient use of fertilizers in successive annual crops (TORRES et al. 2008). 
When choosing a cover crop to supply the biomass required for maintaining a no-tillage system, the climatic conditions of the region must be considered. In the Cerrado, winter is dry and prolonged, and the presence of high temperatures throughout the year hinders biomass from remaining on the soil surface (PACHECO et al. 2008).

An alternative that can contribute to higher efficiency in preserving vegetation cover is the combination of an crop-livestock integration (CLI) system with NTS (MACEDO 2009). The success of this strategy is because the straw accumulated from cover crops and from pasture and crop residues provides an environment that is favorable for the recovery and/or maintenance of the chemical and physical properties of the soil (ASSMANN et al. 2008), while the cover crops promote a high nutrient cycling rate throughout the straw decomposition cycle. This contributes to a decrease in production costs and important environmental gains for the soil and water resources as well as decreased pressure on non-renewable sources of fertilizer (TORRES et al. 2008).

Nutrient availability for the subsequent crop is directly related to nutrient availability in the soil and rate of nutrient release from its residues. Understanding the factors and processes that control nutrient cycling allows nutrient availability to be synchronized with the demands of the subsequent crop (FERREIRA et al. 2011). However, different crops have different capacities to accumulate nutrients in their biomass, with these nutrients subsequently being released into the soil via decomposition of crop residues (NUNES et al. 2010). Some studies have shown the potential of millet, sorghum, corn, Urochloa brizantha and other forage species to accumulate nutrients in their biomass and promote a high rate of nutrient cycling throughout their straw decomposition cycle (TORRES and PEREIRA 2008).

Although the benefits of crop-livestock integration and no-tillage systems are established, information is still lacking regarding nutrient accumulation and release in cover crops in the intercropping of pearl millet with the new cultivar Urochloa brizantha under offseason conditions. Thus, the objective of the present study was to evaluate nutrient cycling and accumulation in the biomass of pearl millet and Paiaguas palisadegrass under different forage systems and sowing periods in integrated crop-livestock.

\section{MATERIALS AND METHODS}

The experiment was conducted in the field $\left(17^{\circ} 48^{\prime} \mathrm{S}\right.$; $50^{\circ} 55^{\prime} \mathrm{W}$; and $748 \mathrm{~m}$ altitude), in the municipality of Rio Verde, Goiás, Brazil, during the 2014 off-season in a Latossolo Vermelho Distroférrico (EMBRAPA 2013), an Oxisol (Soil Survey Staff, 2014).
Soil samples were collected before planting to determine the physical and chemical characteristics of the $0-0.2 \mathrm{~m}$ soil layer. The results were as follows: 600,140 and $260 \mathrm{~g} \mathrm{~kg}^{-1}$ of clay, silt and sand, respectively; $\mathrm{pH}$ in $\mathrm{CaCl}_{2}$ : 6.02 ; Ca: $3.50 \mathrm{cmol}_{\mathrm{c}} \mathrm{dm}^{-3}$; $\mathrm{Mg}: 1.43 \mathrm{cmol}_{\mathrm{c}} \mathrm{dm}^{-3}$; Al: $0.05 \mathrm{cmol}_{\mathrm{c}} \mathrm{dm}^{-3}$; $\mathrm{Al}+\mathrm{H}: 5.90 \mathrm{cmol}_{\mathrm{c}} \mathrm{dm}^{-3} ; \mathrm{K}: 0.35 \mathrm{cmol}_{\mathrm{c}} \mathrm{dm}^{-3}$; CEC: 11.18 $\mathrm{cmol}_{\mathrm{c}} \mathrm{dm}^{-3}$; V: $47.22 \%$; P (Mehlich): $2.29 \mathrm{mg} \mathrm{dm}{ }^{-3}$; Cu: $3.50 \mathrm{mg} \mathrm{dm}^{-3}$; Zn: $5.10 \mathrm{mg} \mathrm{dm}^{-3}$; Fe: $34.1 \mathrm{mg} \mathrm{dm}^{-3}$; O.M.: $37.06 \mathrm{~g} \mathrm{~kg}^{-1}$.

The experiment followed a randomized block design with a $5 \times 2$ factorial arrangement and three replications, comprising five forage systems (monocropped pearl millet, monocropped Paiaguas palisadegrass, pearl millet intercropped in rows with Paiaguas palisadegrass, pearl millet intercropped between rows of Paiaguas palisadegrass and pearl millet oversown and intercropped with Paiaguas palisadegrass) and two sowing periods (February and March). The ADR 8010 pearl millet hybrid, which is medium-sized and dual purpose (grain production and forage), was used. Soil acidity was corrected with $\begin{array}{lllll}\text { calcitic lime with } 100 \quad \% & \text { TRNP }\end{array}$ (total relative neutralizing power), with the application of $675 \mathrm{~kg} \mathrm{ha}^{-1}$ at 30 days before sowing.

One week before implementing the experiment, level harrowing was conducted again, and the field was sown in furrows using a seeder with $0.50-\mathrm{m}$ inter-row spacing. The furrows for sowing Paiaguas palisadegrass in between rows and for oversowing pearl millet were manually dug to a $3 \mathrm{~cm}$ depth using hoes.Sowing was carried out on February 12 and March 4 for the first and second periods, respectively, using $240 \mathrm{~kg} \mathrm{ha}^{-1}$ of $\mathrm{P}_{2} \mathrm{O}_{5}$ (single superphosphate form) and $20 \mathrm{~kg} \mathrm{ha}^{-1}$ of FTE BR 12 fertilizer.

Monocropped and intercropped pearl millet was sown at a $0.03-\mathrm{m}$ depth. Paiaguas palisadegrass was sown in the rows at a $0.06-\mathrm{m}$ depth and in between rows at 0.25 $\mathrm{m}$ from the pearl millet rows, and in the oversown system, it was sown 15 days after sowing pearl millet in the between rows at $0.25 \mathrm{~m}$. For pearl millet, $12 \mathrm{~kg}$ of seeds $\mathrm{ha}^{-1}$ were used, seeking to obtain a final population between 250 and 300 thousand plants $\mathrm{ha}^{-1}$, and $5 \mathrm{~kg}$ of pure viable seeds per hectare were used for the forage species. The plots comprised eight 3.0-m-long rows in all forage systems. The usable area was obtained by only considering the four central rows and eliminating $0.5 \mathrm{~m}$ from the end of each row. At 30 and 50 days after sowing (DAS), $60 \mathrm{~kg} \mathrm{ha}^{-1}$ nitrogen and $40 \mathrm{~kg} \mathrm{ha}^{-1} \mathrm{~K}_{2} \mathrm{O}$ (in urea and potassium chloride forms, respectively) were applied by casting.

Pearl millet grains were manually harvested at 115 and 118 DAS for the first and second sowing periods, respectively, when the plants were at the physiological maturity stage. The remainder of the plants (stems and leaves) were left at the site for the evaluation of straw. 
After the pearl millet was harvested, the dry weight production of the Paiaguas palisadegrass was evaluated in the off-season crop (simulating grazing) over successive cuttings, in which $1-\mathrm{m}^{2}$ samples were collected by randomly placing a quadrat within each plot and cutting at a $0.20-\mathrm{m}$ height from the ground to maintain an adequate residue height to promote grass regrowth.

The first cutting was performed at the time of the pearl millet harvest, on 06/04/14 and 06/24/14 for the first and second periods, respectively. The second cutting occurred 79 days after the first, on $08 / 22 / 14$ (first period), and 72 days after the first, on 09/04/14 (second period). After both cuttings were performed, standard cutting of all plants at the experimental site was carried out, at the same height as for the evaluated plants, and the resulting residue was removed from the site. Next, the Paiaguas palisadegrass was left to rest for regrowth, to allow it desiccate it to form biomass for soybean planting during the next crop season.

Desiccation was conducted on 10/31/14 through application of the herbicide glyphosate at a dose of $4.5 \mathrm{~L}$ $\mathrm{ha}^{-1}\left(588 \mathrm{~g} \mathrm{~L}^{-1}\right)$ and spray volume of $150 \mathrm{~L} \mathrm{ha}^{-1}$. To quantify biomass production, straw samples were collected one day before planting of the soybean crop by randomly placing a $1 \mathrm{~m}^{2}$ quadrat within each plot. The plant material inside the quadrat was cut, using a height of $0.05 \mathrm{~m}$ from the soil surface as a reference. The cut material was weighed, and the samples were dried to constant weight in a forced-air oven at $55^{\circ} \mathrm{C}$, and the amounts were extrapolated to $\mathrm{kg} \mathrm{ha}^{-1}$.

Intacta RR 2 PRO soybean cultivar M 7110 plants were sown under a no-tillage system above the biomass of the forage systems. At sowing, the soybeans were inoculated with strains of Bradyrbizobium japonicum (SEMIA 5079 - CPAC 15 and SEMIA 5080 - CPAC 7), with a minimum guarantee of $7.2 \times 10^{9} \mathrm{CFU} \mathrm{g}^{-1}$ (Biomax Premium Turfa commercial brand) in the following proportion: $60 \mathrm{~g} / 50 \mathrm{~kg}$ of seeds. Sowing was carried out on $11 / 20 / 2014$ using a seeder, with the application of 120 kg ha-1 $\mathrm{P}_{2} \mathrm{O}_{5}, 30 \mathrm{~kg} \mathrm{ha}^{-1} \mathrm{~K}_{2} \mathrm{O}, 2 \mathrm{~kg} \mathrm{ha}{ }^{-1}$ boron, $0.4 \mathrm{~kg} \mathrm{ha}^{-1}$ molybdenum and $6 \mathrm{~kg} \mathrm{ha}^{-1}$ zinc, in the form of single superphosphate, potassium chloride, boric acid, molybdenum sulfate and zinc sulfate, respectively.

Weeds were controlled using the herbicide Transorb (3.5 $\left.\mathrm{L} \mathrm{ha}^{-1}\right)$, with a spray volume of $150 \mathrm{~L} \mathrm{ha}^{-1}$, on $12 / 17 / 14$. One application of the insecticide chlorpyrifos $\left(\mathrm{L} \mathrm{ha}{ }^{-1}\right)$ was performed to control the soybean caterpillar (Anticarsia gemmatalis), and one preventive application of the fungicide azoxystrobin + cyproconazole $\left(0.3 \mathrm{~L} \mathrm{ha}^{-1}\right)$ was performed on $01 / 13 / 2015$.

To quantify biomass production, straw samples were collected by randomly placing a $1 \mathrm{~m}^{2}$ quadrat within each plot. The plant material was cut, using a height of $0.05 \mathrm{~m}$ from the soil surface as a reference. The cut material was weighed, and the samples were dried to constant weight in a forced-air oven at $55^{\circ} \mathrm{C}$, and the amounts were extrapolated to $\mathrm{kg} \mathrm{ha}^{-1}$.

After this management procedure (cutting), the fresh biomass from each plot was placed in nylon litter bags for decomposition (Thomas and Asakawa, 1993). The bags consisted of a 2-mm mesh and measured $15 \times 20 \mathrm{~cm}$. Four bags containing residues of the studied species in an amount proportional to the dry biomass produced per hectare were deposited in direct contact with the soil. At 30, 60, 90 and 120 days after cutting, one litter bag was removed from each plot to evaluate the remaining biomass and determine the decomposition time during the 120-day period (soybean harvest).

After cleaning the material in the laboratory to remove adhered soil, it was dried in an oven at $55^{\circ} \mathrm{C}$ for $72 \mathrm{~h}$ to obtain the dry biomass. Next, samples of the plant material were ground to determine the concentration of the following macronutrients according to the method proposed by Malavolta et al. (1997): nitrogen (N), phosphorus $(\mathrm{P})$, potassium $(\mathrm{K})$, calcium $(\mathrm{Ca})$, magnesium $(\mathrm{Mg})$ and sulfur $(\mathrm{S})$. The macronutrient concentrations were multiplied by the biomass production to evaluate nutrient accumulation in the biomass, and the results are expressed as $\mathrm{kg} \mathrm{ha}^{-1}$.

During the experiment, daily rainfall and the mean monthly temperature were monitored (Figure 1).

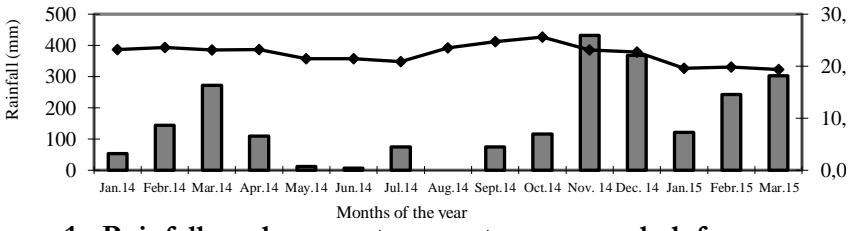

Figure 1. Rainfall and mean temperatures recorded from January to March 2015 in Rio Verde, Goiás, Brazil.

The data were subjected to analysis of variance, and means were compared using Tukey's test at the $5 \%$ significance level. Statistical analyses were performed using SISVAR 4.6 statistical software (FERREIRA 2011).

\section{RESULTS AND DISCUSSION}

The forage system affected $(\mathrm{P}<0.05)$ the concentration and accumulation of nitrogen $(\mathrm{N})$ in the biomass (Table 1). The highest $\mathrm{N}$ concentrations at 30, 60, 90 and 120 days were observed in monocropped Paiaguas palisadegrass and Paiaguas palisadegrass intercropped in the rows and between rows, differing from the oversown and monocropped pearl millet systems. These results are due to the higher proportion of leaves in Paiaguas palisadegrass, concentrating greater amounts of $\mathrm{N}$ in biomass. Regarding the sowing periods, the recorded $\mathrm{N}$ 
concentrations were similar $(\mathrm{P}>0.05)$ at all evaluation times, showing that the sowing period did not affect the $\mathrm{N}$ concentration.

In the evaluation of $\mathrm{N}$ accumulation in biomass, monocropped Paiaguas palisadegrass exhibited higher $\mathrm{N}$ accumulation at all evaluation periods (Table 1), similar to (XAVIER et al., 2014) due to the higher $\mathrm{N}$ concentration and biomass production observed in this system. Thus, the importance of using Paiaguas palisadegrass in intercropped and no-tillage systems when seeking higher system efficiency is notable, as it leads to higher biomass production and consequently higher nutrient accumulation in the biomass.

The amount of $\mathrm{N}$ that returns to the soil in the form of the remaining biomass is a relevant fraction of the total $\mathrm{N}$ absorbed by subsequent plants, even in $\mathrm{N}$-fixing crops, as is the case for soybean. Studies on pearl millet intercropped with tropical forages seeking to determine biomass production under NTS are still scarce (COSTA et al., 2012). However, (MENDONÇA et al., 2015) evaluated nutrient release in forage intercropped with corn and in succession with soybean and observed $70 \mathrm{~kg} \mathrm{ha}^{-1} \mathrm{~N}$ accumulation in Tanzania grass intercropped with corn, sown by simultaneous casting of both crops. This value was lower than we observed in monocropped Paiaguas palisadegrass at 120 days. In exclusive systems (BERNARDES et al., 2010) observed 229 and $327 \mathrm{~kg} \mathrm{ha}^{-1}$ $\mathrm{N}$ accumulation in Marandu palisadegrass and Mombaça grass, respectively, at 75 days after the grasses were cut, corroborating the results observed for monocropped Paiaguas palisadegrass at 30 days, demonstrating the nutrient accumulation potential of Paiaguas palisadegrass. When initial $\mathrm{N}$ accumulation was compared with the values observed at 120 days after the application of management measures (soybean harvesting), the monocropped pearl millet and oversown pearl millet intercropped with Paiaguas palisadegrass exhibited the lowest loss values, which may be explained by pearl millet exhibiting a higher $\mathrm{C} / \mathrm{N}$ ratio compared with Paiaguas palisadegrass and by the lower biomass production of the forage, which cause decomposition and $\mathrm{N}$ mineralization processes to be slower.

The $\mathrm{N}$ is the nutrient that is most extracted by forage species after $\mathrm{K}$ and therefore exhibits higher accumulation in biomass (MENDONÇA et al., 2015). However, a longer period is required for the same amount of extracted $\mathrm{N}$ to be released via mineralization and return to the soil. Once $\mathrm{N}$ is fixed in organic compounds, it is available for cycling in the plant-straw-soil complex (CRUSCIOL et al., 2005).

Regarding the sowing period, the first period exhibited the highest $(\mathrm{P}<0.05) \mathrm{N}$ accumulation values for all forage systems at 30 and 60 days, except for the oversown intercrop. The sowing period affected $\mathrm{N}$ accumulation $(\mathrm{P}<0.05)$ at 90 and 120 days, when only monocropped Paiaguas palisadegrass exhibited higher accumulation, due to the greater dry biomass production observed during the first sowing period.

Regarding the evaluation of the phosphorus $(\mathrm{P})$ concentration during the first and second sowing periods, Table 2 shows that the values were similar $(\mathrm{P}<0.05)$ among the forage systems at 30 and 60 days after the application of the management protocol. Monocropped pearl millet exhibited the lowest value during the second period at 90 and 120 days, differing from pearl millet intercropped in rows and between rows with Paiaguas palisadegrass. These results suggest that the higher biomass production and lower carbon/nitrogen ratio of the monocropped Paiaguas palisadegrass and Paiaguas palisadegrass intercropped in the rows and between rows compared with pearl millet (COSTA et al., 2016) could have contributed to rapid decomposition and $\mathrm{P}$ release.

Assessing the yield and nutrient release from forage crops intercropped with maize for silage, and soybean in succession (MENDONÇA et al., 2015) observed $\mathrm{P}$ accumulation of $13 \mathrm{~kg} \mathrm{ha}^{-1}$ in the biomass of Tanzania grass intercropped with corn at sowing via simultaneous casting; this value is lower than those obtained in the present study in the evaluations conducted at 30, 60 and 90 days. These authors reported that the P contained in organic compounds is usually bound to proteins and molecules involved in energy transport and becomes available for the subsequent crop and/or can be immobilized in poorly soluble mineral compounds. Therefore, it is important to consider that P, even when accumulated in dry biomass, will not be readily available for the subsequent crop. However, when the sowing periods were compared, there was no difference $(\mathrm{P}>0.05)$ observed between the two periods under all of the examined forage systems at all evaluations. 
Table 1. Nitrogen concentration $\left(\mathrm{g} \mathrm{kg}^{-1}\right)$ and accumulation $\left(\mathrm{kg} \mathrm{ha}^{-1}\right)$ in monocropped and intercropped pearl millet and Paiaguas palisadegrass under different forage systems and sowing periods.

\begin{tabular}{llll}
\hline Forage system & \multicolumn{2}{c}{ Sowing period } \\
& First & Second & First Second
\end{tabular}

\begin{tabular}{|c|c|c|c|c|}
\hline \multirow[b]{3}{*}{ Monocropped pearl millet } & \multicolumn{2}{|c|}{ Concentration } & \multicolumn{2}{|c|}{ Accumulation } \\
\hline & \multicolumn{4}{|c|}{30 days } \\
\hline & $11.4 \mathrm{Ca}$ & $9.9 \mathrm{Ca}$ & $104 \mathrm{BCa}$ & $77 \mathrm{Bb}$ \\
\hline Monocropped Paiaguas palisadegrass & $17.6 \mathrm{Aa}$ & $17.0 \mathrm{Aa}$ & $334 \mathrm{Aa}$ & $220 \mathrm{Ab}$ \\
\hline Row pearl millet $\mathrm{x}$ Paiaguas palisadegrass & $18.3 \mathrm{Aa}$ & $17.3 \mathrm{Aa}$ & $180 \mathrm{Ba}$ & $120 \mathrm{Ab}$ \\
\hline Between rows pearl millet $x$ Paiaguas palisadegrass & $16.5 \mathrm{Aa}$ & $17.6 \mathrm{Aa}$ & $132 \mathrm{BCa}$ & $83 \mathrm{Bb}$ \\
\hline Oversown pearl millet x Paiaguas palisadegrass & $13.8 \mathrm{Ba}$ & $13.6 \mathrm{Ba}$ & $48 \mathrm{Ca}$ & $51 \mathrm{Ba}$ \\
\hline \multirow[t]{2}{*}{$\mathrm{CV}(\%)$} & \multicolumn{2}{|c|}{6.34} & \multicolumn{2}{|c|}{37.16} \\
\hline & \multicolumn{4}{|c|}{60 days } \\
\hline Monocropped pearl millet & $12.2 \mathrm{Ca}$ & $10.9 \mathrm{Ca}$ & $91 \mathrm{BCa}$ & $76 \mathrm{Bb}$ \\
\hline Monocropped Paiaguas palisadegrass & $15.3 \mathrm{Aa}$ & $15.0 \mathrm{Aa}$ & $248 \mathrm{Aa}$ & $172 \mathrm{Ab}$ \\
\hline Row pearl millet $\mathrm{x}$ Paiaguas palisadegrass & $16.8 \mathrm{Aa}$ & $16.0 \mathrm{Aa}$ & $138 \mathrm{Ba}$ & $95 \mathrm{Bb}$ \\
\hline Between rows pearl millet $\mathrm{x}$ Paiaguas palisadegrass & $15.5 \mathrm{Aa}$ & $16.5 \mathrm{Aa}$ & $106 \mathrm{BCa}$ & $66 \mathrm{Bb}$ \\
\hline Oversown pearl millet x Paiaguas palisadegrass & 13.6 BCa & $13.2 \mathrm{Ba}$ & $40 \mathrm{Ca}$ & $44,47 \mathrm{Ba}$ \\
\hline \multirow[t]{2}{*}{$\mathrm{CV}(\%)$} & \multicolumn{2}{|c|}{4.88} & \multicolumn{2}{|c|}{35.79} \\
\hline & \multicolumn{4}{|c|}{90 days } \\
\hline Monocropped pearl millet & $11.2 \mathrm{Ca}$ & $11.2 \mathrm{Ca}$ & $75 \mathrm{Ba}$ & $66 \mathrm{Ba}$ \\
\hline Monocropped Paiaguas palisadegrass & $14.8 \mathrm{Aa}$ & 14.6 Aa & $213 \mathrm{Aa}$ & $150 \mathrm{Ab}$ \\
\hline Row pearl millet $\mathrm{x}$ Paiaguas palisadegrass & $15.4 \mathrm{Aa}$ & $15.2 \mathrm{Aa}$ & $102 \mathrm{Ba}$ & $81 \mathrm{Ba}$ \\
\hline Between rows pearl millet $x$ Paiaguas palisadegrass & $15.0 \mathrm{Aa}$ & $15.2 \mathrm{Aa}$ & $85 \mathrm{Ba}$ & $57 \mathrm{Ba}$ \\
\hline Oversown pearl millet x Paiaguas palisadegrass & $13.1 \mathrm{Ba}$ & $12.8 \mathrm{Ba}$ & $36 \mathrm{Ba}$ & $40 \mathrm{Ba}$ \\
\hline \multirow[t]{2}{*}{$\mathrm{CV}(\%)$} & \multicolumn{2}{|c|}{4.58} & \multicolumn{2}{|c|}{36.71} \\
\hline & \multicolumn{4}{|c|}{120 days } \\
\hline Monocropped pearl millet & $11.1 \mathrm{Ca}$ & $10.5 \mathrm{Ca}$ & $66 \mathrm{Ba}$ & $58 \mathrm{Ba}$ \\
\hline Monocropped Paiaguas palisadegrass & $13.8 \mathrm{Aa}$ & $14.2 \mathrm{Aa}$ & $176 \mathrm{Aa}$ & $135 \mathrm{Ab}$ \\
\hline Row pearl millet $\mathrm{x}$ Paiaguas palisadegrass & $14.4 \mathrm{Aa}$ & $14.1 \mathrm{Aa}$ & $79 \mathrm{Ba}$ & $70 \mathrm{Ba}$ \\
\hline Between rows pearl millet $x$ Paiaguas palisadegrass & $14.0 \mathrm{Aa}$ & $14.7 \mathrm{Aa}$ & $71 \mathrm{Ba}$ & $51 \mathrm{Ba}$ \\
\hline Oversown pearl millet x Paiaguas palisadegrass & $12.5 \mathrm{Ba}$ & $12.4 \mathrm{Ba}$ & $31 \mathrm{Ba}$ & $35 \mathrm{Ba}$ \\
\hline $\mathrm{CV}(\%)$ & \multicolumn{2}{|c|}{4.92} & \multicolumn{2}{|c|}{29.99} \\
\hline
\end{tabular}

Means followed by different uppercase letters in the columns (forage systems) and lowercase letters in the rows (sowing periods) differ from each other according to Tukey's test at the $5 \%$ probability level.

Regarding $\mathrm{P}$ accumulation in the biomass of the forage systems, monocropped Paiaguas palisadegrass exhibited higher accumulation compared with the intercropped systems and monocropped pearl millet at all evaluations (Table 2). The $\mathrm{P}$ accumulation of $38 \mathrm{~kg} \mathrm{ha}^{-1}$ and $20 \mathrm{~kg} \mathrm{ha}^{-1}$ in the biomass of ADR 500 millet and Xaraes palisadegrass, respectively, during the 2009/2010 crop season (COSTA et al., 2015). This difference in accumulation compared with monocropped pearl millet is mainly due to biomass production, as the ADR 500 variety is intended for forage production and thus presents greater genetic potential for this type of production compared with the ADR 8010 hybrid. Paiaguas palisadegrass exhibited $\mathrm{P}$ values similar to xaraes 
Table 2. Phosphorus concentration $\left(\mathrm{g} \mathrm{kg}^{-1}\right)$ and accumulation $\left(\mathrm{kg} \mathrm{ha}^{-1}\right)$ in monocropped and intercropped pearl millet and Paiaguas palisadegrass under different forage systems and sowing periods.

\begin{tabular}{|c|c|c|c|c|}
\hline \multirow[t]{2}{*}{ Forage system } & \multicolumn{4}{|c|}{ Sowing period } \\
\hline & First & Second & First & Second \\
\hline & \multicolumn{3}{|c|}{ Concentration } & mulation \\
\hline & \multicolumn{4}{|c|}{30 days } \\
\hline Monocropped pearl millet & $1.2 \mathrm{Aa}$ & $1.4 \mathrm{Aa}$ & $10 \mathrm{Ba}$ & $10 \mathrm{Ba}$ \\
\hline Monocropped Paiaguas palisadegrass & $1.5 \mathrm{Aa}$ & 1.6 Aa & $23 \mathrm{Aa}$ & $20 \mathrm{Aa}$ \\
\hline Row pearl millet x Paiaguas palisadegrass & $1.2 \mathrm{Aa}$ & $1.5 \mathrm{Aa}$ & $12 \mathrm{Ba}$ & $11 \mathrm{Ba}$ \\
\hline Between rows pearl millet $\mathrm{x}$ Paiaguas palisadegrass & $1.4 \mathrm{Aa}$ & 1.6 Aa & $11 \mathrm{Ba}$ & $7 \mathrm{Ba}$ \\
\hline Oversown pearl millet x Paiaguas palisadegrass & $1.4 \mathrm{Aa}$ & $1.3 \mathrm{Aa}$ & $5 \mathrm{Ba}$ & $5 \mathrm{Ba}$ \\
\hline $\mathrm{CV}(\%)$ & \multicolumn{2}{|c|}{11.33} & \multicolumn{2}{|c|}{30.20} \\
\hline Monocropped pearl millet & $1.0 \mathrm{Aa}$ & $1.1 \mathrm{Aa}$ & $8 \mathrm{BCa}$ & $8 \mathrm{Ba}$ \\
\hline Monocropped Paiaguas palisadegrass & $1.2 \mathrm{Aa}$ & $1.4 \mathrm{Aa}$ & $15 \mathrm{Aa}$ & $17 \mathrm{Aa}$ \\
\hline Row pearl millet $\mathrm{x}$ Paiaguas palisadegrass & $1.2 \mathrm{Aa}$ & $1.3 \mathrm{Aa}$ & $10 \mathrm{ABa}$ & $8 \mathrm{Ba}$ \\
\hline Between rows pearl millet $x$ Paiaguas palisadegrass & $1.2 \mathrm{Aa}$ & $1.2 \mathrm{Aa}$ & $8 \mathrm{BCa}$ & $5 \mathrm{Ba}$ \\
\hline Oversown pearl millet x Paiaguas palisadegrass & $1.0 \mathrm{Aa}$ & $1.2 \mathrm{Aa}$ & $3 \mathrm{Ca}$ & $4 \mathrm{Ba}$ \\
\hline $\mathrm{CV}(\%)$ & \multicolumn{2}{|c|}{17.40} & \multicolumn{2}{|c|}{29.66} \\
\hline Monocropped pearl millet & $1.1 \mathrm{Aa}$ & $0.9 \mathrm{Ba}$ & $8 \mathrm{Ba}$ & $7 \mathrm{Ba}$ \\
\hline Monocropped Paiaguas palisadegrass & $1.0 \mathrm{Aa}$ & $1.1 \mathrm{ABa}$ & $14 \mathrm{Aa}$ & $15 \mathrm{Aa}$ \\
\hline Row pearl millet x Paiaguas palisadegrass & $1.1 \mathrm{Aa}$ & $1.2 \mathrm{Aa}$ & $8 \mathrm{Ba}$ & $7 \mathrm{Ba}$ \\
\hline Between rows pearl millet x Paiaguas palisadegrass & $1.2 \mathrm{Aa}$ & $1.2 \mathrm{Aa}$ & $7 \mathrm{Ba}$ & $4 \mathrm{Ba}$ \\
\hline Oversown pearl millet x Paiaguas palisadegrass & $1.0 \mathrm{Aa}$ & $1.1 \mathrm{ABa}$ & $3 \mathrm{Ba}$ & $4 \mathrm{Ba}$ \\
\hline $\mathrm{CV}(\%)$ & \multicolumn{2}{|c|}{10.28} & \multicolumn{2}{|c|}{28.69} \\
\hline Monocropped pearl millet & $1.0 \mathrm{Aa}$ & $0.9 \mathrm{Ba}$ & $7 \mathrm{Ba}$ & $5 \mathrm{Ba}$ \\
\hline Monocropped Paiaguas palisadegrass & $1.1 \mathrm{Aa}$ & $1.1 \mathrm{ABa}$ & $12 \mathrm{Aa}$ & $11 \mathrm{Aa}$ \\
\hline Row pearl millet x Paiaguas palisadegrass & $1.1 \mathrm{Aa}$ & $1.2 \mathrm{Aa}$ & $6 \mathrm{Ba}$ & $6 \mathrm{Ba}$ \\
\hline Between rows pearl millet $x$ Paiaguas palisadegrass & $1.2 \mathrm{Aa}$ & $1.2 \mathrm{Aa}$ & $6 \mathrm{Ba}$ & $4 \mathrm{Ba}$ \\
\hline Oversown pearl millet x Paiaguas palisadegrass & $1.0 \mathrm{Aa}$ & $1.1 \mathrm{ABa}$ & $2 \mathrm{Ba}$ & $3 \mathrm{Ba}$ \\
\hline $\mathrm{CV}(\%)$ & \multicolumn{2}{|c|}{10.28} & \multicolumn{2}{|c|}{27.84} \\
\hline
\end{tabular}

Means followed by different uppercase letters in the columns (forage systems) and lowercase letters in the rows (sowing periods) differ from each other according to Tukey's test at the $5 \%$ probability level.

grass; however, the planting of cover crops in the study (COSTA et al., 2015) occurred during the summer, resulting in the production of a greater amount of biomass.

The intensity and duration of rainfall is a factor that can increase the amount of $\mathrm{P}$ that returns to the soil from the remaining biomass (COSTA et al., 2012). Therefore, the rainfall that occurred during the evaluation of litter bags between November 2014 and February 2015 (Figure 1), which exhibited a mean value of $290.5 \mathrm{~mm}$, may have favored the release of a portion of the $\mathrm{P}$ present in the biomass to the soil system. 
Table 3. Potassium concentration $\left(\mathrm{g} \mathrm{kg}^{-1}\right)$ and accumulation $\left(\mathrm{kg} \mathrm{ha}^{-1}\right)$ in monocropped and intercropped pearl millet and Paiaguas palisadegrass under different forage systems and sowing periods.

\begin{tabular}{|c|c|c|c|c|}
\hline \multirow[t]{2}{*}{ Forage system } & \multicolumn{4}{|c|}{ Sowing period } \\
\hline & First & Second & First & Second \\
\hline & \multicolumn{2}{|c|}{ Concentration } & \multicolumn{2}{|c|}{ Accumulation } \\
\hline & \multicolumn{4}{|c|}{30 days } \\
\hline Monocropped pearl millet & 16.7 BCa & $10.0 \mathrm{Ba}$ & $115 \mathrm{Ca}$ & $88 \mathrm{Ca}$ \\
\hline Monocropped Paiaguas palisadegrass & $40.0 \mathrm{Aa}$ & $34.7 \mathrm{Aa}$ & $628 \mathrm{Aa}$ & $417 \mathrm{Ab}$ \\
\hline Row pearl millet x Paiaguas palisadegrass & $36.7 \mathrm{Aa}$ & $26.7 \mathrm{Aa}$ & $343 \mathrm{Ba}$ & $183 \mathrm{Bb}$ \\
\hline Between rows pearl millet $\mathrm{x}$ Paiaguas palisadegrass & $33.3 \mathrm{Aa}$ & $30.0 \mathrm{Aa}$ & $259 \mathrm{Ba}$ & $121 \mathrm{Bb}$ \\
\hline Oversown pearl millet x Paiaguas palisadegrass & $12.0 \mathrm{Ca}$ & $10.0 \mathrm{Ba}$ & $42 \mathrm{Da}$ & $36 \mathrm{Da}$ \\
\hline \multirow[t]{2}{*}{$\mathrm{CV}(\%)$} & \multicolumn{2}{|c|}{28.57} & \multicolumn{2}{|c|}{27.06} \\
\hline & \multicolumn{4}{|c|}{60 days } \\
\hline Monocropped pearl millet & $10.0 \mathrm{Ba}$ & $10.0 \mathrm{Aa}$ & $78 \mathrm{Ca}$ & $60 \mathrm{Ba}$ \\
\hline Monocropped Paiaguas palisadegrass & $33.3 \mathrm{Aa}$ & $23.3 \mathrm{Ab}$ & $436 \mathrm{Aa}$ & $260 \mathrm{Ab}$ \\
\hline Row pearl millet $\mathrm{x}$ Paiaguas palisadegrass & $26.7 \mathrm{Aa}$ & $10.0 \mathrm{Ab}$ & $207 \mathrm{Ba}$ & $77 \mathrm{Bb}$ \\
\hline Between rows pearl millet x Paiaguas palisadegrass & $23.3 \mathrm{Aa}$ & $20.0 \mathrm{Aa}$ & $161 \mathrm{Ba}$ & $76 \mathrm{Bb}$ \\
\hline Oversown pearl millet x Paiaguas palisadegrass & $10.0 \mathrm{Ba}$ & $10.0 \mathrm{Aa}$ & $30 \mathrm{Da}$ & $31 \mathrm{Ca}$ \\
\hline $\mathrm{CV}(\%)$ & \multicolumn{2}{|c|}{31.00} & \multicolumn{2}{|c|}{26.74} \\
\hline
\end{tabular}

\begin{tabular}{|c|c|c|c|c|}
\hline \multirow[b]{2}{*}{ Monocropped pearl millet } & \multicolumn{4}{|c|}{90 days } \\
\hline & $10.0 \mathrm{Ba}$ & $10.0 \mathrm{Aa}$ & $59 \mathrm{Ca}$ & $44 \mathrm{Ba}$ \\
\hline Monocropped Paiaguas palisadegrass & $23.3 \mathrm{Aa}$ & $16.6 \mathrm{Ab}$ & $282 \mathrm{Aa}$ & $158 \mathrm{Ab}$ \\
\hline Row pearl millet $\mathrm{x}$ Paiaguas palisadegrass & $20.0 \mathrm{Aa}$ & $10.0 \mathrm{Ab}$ & $112 \mathrm{Ba}$ & $61 \mathrm{Bb}$ \\
\hline Between rows pearl millet x Paiaguas palisadegrass & $20.0 \mathrm{Aa}$ & $10.0 \mathrm{Ab}$ & $96 \mathrm{Ba}$ & $39 \mathrm{Bb}$ \\
\hline Oversown pearl millet x Paiaguas palisadegrass & $10.0 \mathrm{Ba}$ & $10.0 \mathrm{Aa}$ & $24 \mathrm{Da}$ & $27 \mathrm{Ca}$ \\
\hline \multirow[t]{2}{*}{$\mathrm{CV}(\%)$} & \multicolumn{2}{|c|}{29.80} & \multicolumn{2}{|c|}{46.95} \\
\hline & \multicolumn{4}{|c|}{120 days } \\
\hline Monocropped pearl millet & $3.3 \mathrm{Ba}$ & $6.7 \mathrm{Aa}$ & $34 \mathrm{BCa}$ & $35 \mathrm{Ba}$ \\
\hline Monocropped Paiaguas palisadegrass & $16.7 \mathrm{Aa}$ & $10.0 \mathrm{Aa}$ & $168 \mathrm{Aa}$ & $124 \mathrm{Ab}$ \\
\hline Row pearl millet x Paiaguas palisadegrass & $10.0 \mathrm{ABa}$ & $10.0 \mathrm{Aa}$ & $49 \mathrm{Ba}$ & $45 \mathrm{Ba}$ \\
\hline Between rows pearl millet $\mathrm{x}$ Paiaguas palisadegrass & $10.0 \mathrm{ABa}$ & $10.0 \mathrm{Aa}$ & $61 \mathrm{Ba}$ & $32 \mathrm{Bb}$ \\
\hline Oversown pearl millet x Paiaguas palisadegrass & $6.7 \mathrm{Ba}$ & $6.7 \mathrm{Aa}$ & $14 \mathrm{Ca}$ & $17 \mathrm{Ca}$ \\
\hline $\mathrm{CV}(\%)$ & \multicolumn{2}{|c|}{46.36} & \multicolumn{2}{|c|}{31.27} \\
\hline
\end{tabular}

Means followed by different uppercase letters in the columns (forage systems) and lowercase letters in the rows (sowing periods) differ from each other according to Tukey's test at the $5 \%$ probability level.

Table 3 shows data on the concentration and accumulation of potassium $(K)$ in the biomass of the forage systems. $\mathrm{K}$ concentrations recorded at 30 days in both sowing periods and at 60, 90 and 120 days in the first period were highest $(\mathrm{P}<0.05)$ in monocropped Paiaguas palisadegrass, followed by the row and inter-row intercrop systems. These results can be explained by two factors: the first is the higher biomass production in this system (COSTA et al., 2016), and the second is the high $\mathrm{K}$ accumulation capacity in the biomass of forage grasses, where $\mathrm{K}$ is the most accumulated nutrient (COSTA et al., 2015). However, there was no difference $(\mathrm{P}>0.05)$ among 
Table 4. Calcium concentration $\left(\mathrm{g} \mathrm{kg}^{-1}\right)$ and accumulation $\left(\mathrm{kg} \mathrm{ha}^{-1}\right)$ in monocropped and intercropped pearl millet and Paiaguas palisadegrass under different forage systems and sowing periods.

\begin{tabular}{|c|c|c|c|c|}
\hline \multirow[t]{2}{*}{ Forage system } & \multicolumn{4}{|c|}{ Sowing period } \\
\hline & First & Second & First & Second \\
\hline & \multicolumn{2}{|c|}{ Concentration } & \multicolumn{2}{|c|}{ Accumulation } \\
\hline & \multicolumn{2}{|c|}{30 days } & & \\
\hline Monocropped pearl millet & $1.4 \mathrm{Ba}$ & $1.2 \mathrm{Ba}$ & $21 \mathrm{Ba}$ & $17 \mathrm{Ba}$ \\
\hline Monocropped Paiaguas palisadegrass & 3.6 Aa & $2.1 \mathrm{Ab}$ & $36 \mathrm{Aa}$ & $24 \mathrm{Ab}$ \\
\hline Row pearl millet x Paiaguas palisadegrass & $2.3 \mathrm{Aa}$ & $2.4 \mathrm{Aa}$ & $19 \mathrm{Ba}$ & $11 \mathrm{Ba}$ \\
\hline Between rows pearl millet $\mathrm{x}$ Paiaguas palisadegrass & $3.3 \mathrm{Aa}$ & $2.7 \mathrm{Aa}$ & $18 \mathrm{Ba}$ & $8 \mathrm{BCb}$ \\
\hline Oversown pearl millet x Paiaguas palisadegrass & $1.5 \mathrm{Ba}$ & $1.5 \mathrm{Ba}$ & $8 \mathrm{Ba}$ & $5 \mathrm{BCa}$ \\
\hline \multirow[t]{2}{*}{$\mathrm{CV}(\%)$} & \multicolumn{2}{|c|}{25.85} & \multicolumn{2}{|c|}{31.65} \\
\hline & \multicolumn{4}{|c|}{60 days } \\
\hline Monocropped pearl millet & $1.5 \mathrm{Ba}$ & $1.2 \mathrm{Ba}$ & $15 \mathrm{Ba}$ & $9 \mathrm{Aa}$ \\
\hline Monocropped Paiaguas palisadegrass & $2.6 \mathrm{Aa}$ & $1.7 \mathrm{Aa}$ & $26 \mathrm{Aa}$ & $17 \mathrm{Ab}$ \\
\hline Row pearl millet x Paiaguas palisadegrass & $2.1 \mathrm{Aa}$ & $1.5 \mathrm{Aa}$ & $12 \mathrm{BCa}$ & $7 \mathrm{Ba}$ \\
\hline Between rows pearl millet x Paiaguas palisadegrass & $2.0 \mathrm{Aa}$ & $1.7 \mathrm{Aa}$ & $12 \mathrm{BCa}$ & $6 \mathrm{Bb}$ \\
\hline Oversown pearl millet $\mathrm{x}$ Paiaguas palisadegrass & $1.2 \mathrm{Ba}$ & $1.1 \mathrm{Ba}$ & $5 \mathrm{Ca}$ & $5 \mathrm{Ba}$ \\
\hline $\mathrm{CV}(\%)$ & \multicolumn{2}{|c|}{35.01} & \multicolumn{2}{|c|}{31.45} \\
\hline
\end{tabular}

Monocropped pearl millet

Monocropped Paiaguas palisadegrass

Row pearl millet x Paiaguas palisadegrass

Between rows pearl millet $x$ Paiaguas palisadegrass

Oversown pearl millet $\mathrm{x}$ Paiaguas palisadegrass

CV $(\%)$

Monocropped pearl millet

Monocropped Paiaguas palisadegrass

Row pearl millet x Paiaguas palisadegrass

Between rows pearl millet $x$ Paiaguas palisadegrass

Oversown pearl millet $\mathrm{x}$ Paiaguas palisadegrass

$\mathrm{CV}(\%)$

$\begin{array}{llcl}1.5 \mathrm{Aa} & 0.6 \mathrm{Bb} & 12 \mathrm{ABa} & 10 \mathrm{Ba} \\ 1.6 \mathrm{Aa} & 1.5 \mathrm{Aa} & 20 \mathrm{Aa} & 17 \mathrm{Aa} \\ 1.5 \mathrm{Aa} & 1.3 \mathrm{Aa} & 9 \mathrm{Ba} & 6 \mathrm{Ba} \\ 1.7 \mathrm{Aa} & 1.4 \mathrm{Aa} & 10 \mathrm{Ba} & 4 \mathrm{Bb} \\ 1.3 \mathrm{Aa} & 0.8 \mathrm{Ba} & 4 \mathrm{Ba} & 3 \mathrm{Ba}\end{array}$

26.15

33.99

\section{0 days}

$1.4 \mathrm{Aa} \quad 1.1 \mathrm{Ab} \quad 9 \mathrm{ABa} \quad 9 \mathrm{ABa}$

$1.5 \mathrm{Aa} \quad 1.1 \mathrm{Ab} \quad 14 \mathrm{Aa} \quad 14 \mathrm{Aa}$

$1.4 \mathrm{Aa} \quad 1.1 \mathrm{Ab} \quad 5 \mathrm{Ba} \quad 6 \mathrm{Ba}$

$1.3 \mathrm{Aa} \quad 0.9 \mathrm{Ab} \quad 9 \mathrm{ABa} \quad 6 \mathrm{Ba}$

$\begin{array}{llll}1.0 \mathrm{Ba} & 1.0 \mathrm{Aa} & 3 \mathrm{Ba} & 3 \mathrm{Ba}\end{array}$

Means followed by different uppercase letters in the columns (forage systems) and lowercase letters in the rows (sowing periods) differ from each other according to Tukey's test at the $5 \%$ probability level.

the systems in the second sowing period starting at the 60 day evaluation, as similar $\mathrm{K}$ concentration values were observed.

It is important to note that unlike $\mathrm{N}, \mathrm{K}$ is not a component of complex structural molecules in plant tissue and is therefore easily released to the subsequent crop according to the amount accumulated in biomass
(ROSOLEM et al., 2003), without a need for decomposition for this to occur.

The effect of the sowing period $(\mathrm{P}<0.05)$ on the $\mathrm{K}$ concentration in the biomass was only evident at 60 days in monocropped Paiaguas palisadegrass and Paiaguas palisadegrass intercropped in rows and at 90 days in monocropped Paiaguas palisadegrass and Paiaguas 
Table 5. Magnesium concentration $\left(\mathrm{g} \mathrm{kg}^{-1}\right)$ and accumulation $\left(\mathrm{kg} \mathrm{ha}^{-1}\right)$ in monocropped and intercropped pearl millet and Paiaguas palisadegrass under different forage systems and sowing periods.

\begin{tabular}{|c|c|c|c|c|}
\hline \multirow[t]{2}{*}{ Forage system } & \multicolumn{4}{|c|}{ Sowing period } \\
\hline & First & Second & First & Second \\
\hline & \multicolumn{2}{|c|}{ Concentration } & \multicolumn{2}{|c|}{ Accumulation } \\
\hline & \multicolumn{4}{|c|}{30 days } \\
\hline Monocropped pearl millet & 4.1 Aa & $3.6 \mathrm{Aa}$ & $34 \mathrm{BCa}$ & $26 \mathrm{ABa}$ \\
\hline Monocropped Paiaguas palisadegrass & 4.4 Aa & $3.8 \mathrm{Aa}$ & $69 \mathrm{Aa}$ & $49 \mathrm{Ab}$ \\
\hline Row pearl millet x Paiaguas palisadegrass & 4.4 Aa & $4.0 \mathrm{Aa}$ & $43 \mathrm{Ba}$ & $28 \mathrm{ABa}$ \\
\hline Between rows pearl millet x Paiaguas palisadegrass & 4.7 Aa & 4.0 Aa & $37 \mathrm{BCa}$ & $15 \mathrm{Bb}$ \\
\hline Oversown pearl millet x Paiaguas palisadegrass & 4.4 Aa & $3.6 \mathrm{Aa}$ & $15 \mathrm{Ca}$ & $12 \mathrm{Ba}$ \\
\hline \multirow[t]{2}{*}{$\mathrm{CV}(\%)$} & \multicolumn{2}{|c|}{10.63} & \multicolumn{2}{|c|}{32.41} \\
\hline & \multicolumn{4}{|c|}{60 days } \\
\hline Monocropped pearl millet & 3.6 Aa & $3.2 \mathrm{Aa}$ & $28 \mathrm{Ba}$ & $22 \mathrm{Aa}$ \\
\hline Monocropped Paiaguas palisadegrass & $3.7 \mathrm{Aa}$ & $3.7 \mathrm{Aa}$ & $47 \mathrm{Aa}$ & $29 \mathrm{Ab}$ \\
\hline Row pearl millet x Paiaguas palisadegrass & 3.9 Aa & $3.6 \mathrm{Aa}$ & $32 \mathrm{ABa}$ & $22 \mathrm{Aa}$ \\
\hline Between rows pearl millet x Paiaguas palisadegrass & 4.2 Aa & $3.5 \mathrm{Aa}$ & $28 \mathrm{Ba}$ & $15 \mathrm{Ab}$ \\
\hline Oversown pearl millet x Paiaguas palisadegrass & $3.8 \mathrm{Aa}$ & $3.4 \mathrm{Aa}$ & $10 \mathrm{Ba}$ & $12 \mathrm{Aa}$ \\
\hline \multirow[t]{2}{*}{$\mathrm{CV}(\%)$} & \multicolumn{2}{|c|}{11.12} & \multicolumn{2}{|c|}{40.50} \\
\hline & \multicolumn{4}{|c|}{90 days } \\
\hline Monocropped pearl millet & $3.3 \mathrm{Aa}$ & $3.7 \mathrm{Aa}$ & $23 \mathrm{BCa}$ & $24 \mathrm{ABa}$ \\
\hline Monocropped Paiaguas palisadegrass & 3.6 Aa & $3.3 \mathrm{Aa}$ & $43 \mathrm{Aa}$ & $34 \mathrm{Ab}$ \\
\hline Row pearl millet x Paiaguas palisadegrass & $3.8 \mathrm{Aa}$ & 3.6 Aa & $25 \mathrm{Ba}$ & $19 \mathrm{Ba}$ \\
\hline Between rows pearl millet x Paiaguas palisadegrass & 3.9 $\mathrm{Aa}$ & $3.0 \mathrm{Aa}$ & $22 \mathrm{BCa}$ & $12 \mathrm{Bb}$ \\
\hline Oversown pearl millet x Paiaguas palisadegrass & $3.5 \mathrm{Aa}$ & $3.3 \mathrm{Aa}$ & $10 \mathrm{Ca}$ & $11 \mathrm{Ba}$ \\
\hline \multirow[t]{2}{*}{$\mathrm{CV}(\%)$} & \multicolumn{2}{|c|}{10.51} & \multicolumn{2}{|c|}{27.09} \\
\hline & \multicolumn{4}{|c|}{120 days } \\
\hline Monocropped pearl millet & 3.6 Aa & $3.1 \mathrm{Aa}$ & $20 \mathrm{ABa}$ & $19 \mathrm{ABa}$ \\
\hline Monocropped Paiaguas palisadegrass & $3.2 \mathrm{Aa}$ & 2.9 Aa & $35 \mathrm{Aa}$ & $25 \mathrm{Ab}$ \\
\hline Row pearl millet x Paiaguas palisadegrass & $3.3 \mathrm{Aa}$ & $3.2 \mathrm{Aa}$ & $18 \mathrm{ABa}$ & $16 \mathrm{ABa}$ \\
\hline Between rows pearl millet $\mathrm{x}$ Paiaguas palisadegrass & $3.4 \mathrm{Aa}$ & $2.8 \mathrm{Aa}$ & $18 \mathrm{ABa}$ & $10 \mathrm{Bb}$ \\
\hline Oversown pearl millet x Paiaguas palisadegrass & $3.3 \mathrm{Aa}$ & $3.0 \mathrm{Aa}$ & $8 \mathrm{Ba}$ & $9 \mathrm{Ba}$ \\
\hline CV $(\%)$ & \multicolumn{2}{|c|}{14.54} & \multicolumn{2}{|c|}{29.38} \\
\hline
\end{tabular}

Means followed by different uppercase letters in the columns (forage systems) and lowercase letters in the rows (sowing periods) differ from each other according to Tukey's test at the $5 \%$ probability level.

palisadegrass intercropped in rows and between rows. The first sowing period led to higher $\mathrm{K}$ concentrations at both evaluations.

Regarding $\mathrm{K}$ accumulation in the biomass of the examined systems, monocropped Paiaguas palisadegrass differed $(\mathrm{P}<0.05)$ from the other forage systems, exhibiting higher accumulation values at all evaluation periods. This result is associated with the higher biomass production of the forage (COSTA et al., 2016). In contrast, the oversown pearl millet Paiaguas palisadegrass intercrop exhibited the lowest accumulation of $\mathrm{K}$ in the biomass, similar to the other nutrients discussed above, which may be explained by the low biomass production observed in this system, due to the effect of competition (COSTA et al., 2016). 
Table 6. Sulfur concentration $\left(\mathrm{g} \mathrm{kg}^{-1}\right)$ and accumulation $\left(\mathrm{kg} \mathrm{ha}^{-1}\right)$ in monocropped and intercropped pearl millet and Paiaguas palisadegrass under different forage systems and sowing periods.

\begin{tabular}{|c|c|c|c|c|}
\hline \multirow[t]{2}{*}{ Forage system } & \multicolumn{4}{|c|}{ Sowing period } \\
\hline & First & Second & First & Second \\
\hline & \multicolumn{2}{|c|}{ Concentration } & \multicolumn{2}{|c|}{ Accumulation } \\
\hline & \multicolumn{4}{|c|}{30 days } \\
\hline Monocropped pearl millet & $1.3 \mathrm{Aa}$ & $1.3 \mathrm{Aa}$ & $10 \mathrm{BCa}$ & $10 \mathrm{Ca}$ \\
\hline Monocropped Paiaguas palisadegrass & $1.2 \mathrm{Aa}$ & $1.1 \mathrm{Aa}$ & $20 \mathrm{Aa}$ & $17 \mathrm{Aa}$ \\
\hline Row pearl millet x Paiaguas palisadegrass & $1.2 \mathrm{Aa}$ & $1.3 \mathrm{Aa}$ & $16 \mathrm{ABa}$ & $12 \mathrm{Ba}$ \\
\hline Between rows pearl millet $\mathrm{x}$ Paiaguas palisadegrass & $1.1 \mathrm{Aa}$ & $1.0 \mathrm{Aa}$ & $13 \mathrm{ABa}$ & $10 \mathrm{Ba}$ \\
\hline Oversown pearl millet x Paiaguas palisadegrass & $0.9 \mathrm{Aa}$ & $1.0 \mathrm{Aa}$ & $5 \mathrm{Ca}$ & $5 \mathrm{Ca}$ \\
\hline $\mathrm{CV}(\%)$ & \multicolumn{2}{|c|}{16.60} & \multicolumn{2}{|c|}{30.28} \\
\hline
\end{tabular}

$\begin{array}{llccc}\text { Monocropped pearl millet } & 1.3 \mathrm{Aa} & 1.3 \mathrm{Aa} & 10 \mathrm{ABa} & 8 \mathrm{ABa} \\ \text { Monocropped Paiaguas palisadegrass } & 1.2 \mathrm{Aa} & 1.1 \mathrm{Aa} & 16 \mathrm{Aa} & 12 \mathrm{Aa} \\ \text { Row pearl millet x Paiaguas palisadegrass } & 1.2 \mathrm{Aa} & 1.3 \mathrm{Aa} & 10 \mathrm{ABa} & 8 \mathrm{ABa} \\ \text { Between rows pearl millet x Paiaguas palisadegrass } & 1.1 \mathrm{Aa} & 1.0 \mathrm{Aa} & 7 \mathrm{BCa} & 4 \mathrm{Ba} \\ \text { Oversown pearl millet x Paiaguas palisadegrass } & 0.9 \mathrm{Aa} & 1.0 \mathrm{Aa} & 3 \mathrm{Ca} & 3 \mathrm{Ba} \\ \mathrm{CV}(\%) & & 16.60 & 30.13\end{array}$

Monocropped pearl millet

$\begin{array}{llll}1.1 \mathrm{Aa} & 1.0 \mathrm{Aa} & 7 \mathrm{Ba} & 7 \mathrm{ABa}\end{array}$

Monocropped Paiaguas palisadegrass

$1.1 \mathrm{Aa} \quad 1.0 \mathrm{Aa} \quad 13 \mathrm{Aa} \quad 10 \mathrm{Aa}$

Row pearl millet x Paiaguas palisadegrass

$0.9 \mathrm{Aa}$

$1.1 \mathrm{Aa}$

$6 \mathrm{BCa}$

$6 \mathrm{Ba}$

Between rows pearl millet $x$ Paiaguas palisadegrass

$1.0 \mathrm{Aa}$

$1.0 \mathrm{Aa}$

$5 \mathrm{BCa}$

$4 \mathrm{Ba}$

Oversown pearl millet $\mathrm{x}$ Paiaguas palisadegrass

$1.0 \mathrm{Aa}$

$1.0 \mathrm{Aa}$

$3 \mathrm{Ca}$

$3 \mathrm{Ba}$

CV $(\%)$ 15.04 26.39

Monocropped pearl millet

Monocropped Paiaguas palisadegrass

Row pearl millet x Paiaguas palisadegrass

Between rows pearl millet $x$ Paiaguas palisadegrass

Oversown pearl millet $\mathrm{x}$ Paiaguas palisadegrass

$\mathrm{CV}(\%)$

\begin{tabular}{lrrr}
$1.1 \mathrm{Aa}$ & $1.1 \mathrm{Aa}$ & $7 \mathrm{ABa}$ & $7 \mathrm{ABa}$ \\
$0.7 \mathrm{Ba}$ & $0.8 \mathrm{Ba}$ & $8 \mathrm{Aa}$ & $8 \mathrm{Aa}$ \\
$0.9 \mathrm{ABa}$ & $0.9 \mathrm{ABa}$ & $5 \mathrm{BCa}$ & $5 \mathrm{BCa}$ \\
$0.8 \mathrm{Bb}$ & $1.0 \mathrm{ABa}$ & $4 \mathrm{Ca}$ & $4 \mathrm{Ca}$ \\
$1.1 \mathrm{Aa}$ & $1.0 \mathrm{ABa}$ & $3 \mathrm{Ca}$ & $3 \mathrm{Ca}$ \\
\multicolumn{2}{c}{11.51} & &
\end{tabular}

Means followed by different uppercase letters in the columns (forage systems) and lowercase letters in the rows (sowing periods) differ from each other according to Tukey's test at the $5 \%$ probability level.

It is noteworthy that $\mathrm{K}$ was the macronutrient exhibiting the highest accumulation in the biomass, followed by N, corroborating the results obtained (PARIZ et al., 2011; COSTA et al., 2015; MENDONÇA et al., 2015). According to various studies, $K$ and $N$ are the nutrients exhibiting the highest absorption and accumulation in the plant tissue of cover crops. Additionally, the high $\mathrm{K}$ accumulation observed in the present study for Paiaguas palisadegrass that was monocropped or intercropped in rows or between rows indicates that Urochloa brizantha cultivars extract large amounts of $\mathrm{K}$ from the soil, accumulating this $\mathrm{K}$ in their biomass, as observed in other studies (COSTA et al., 2015).

When initial $\mathrm{K}$ accumulation was compared with the values recorded during the last evaluation at 120 days after the application of management procedures, decreases 
of $70,73,85,76$ and $66 \%$ were observed for monocropped pearl millet and Paiaguas palisadegrass and the row, interrow and oversown intercrop systems, respectively, during the first sowing period. For the same sequence during the second period, decreases of $60,70,75,74$ and $50 \%$ were recorded. The observed decreases in $\mathrm{K}$ were greater compared with the other nutrients most likely due to $\mathrm{K}$ being easily extracted from straw, without requiring the biological processes of decomposition and mineralization because $\mathrm{K}$ is not part of the plant as a structural constituent (ROSOLEM et al., 2003). According to Santos et al. (2008), the amount of $\mathrm{K}$ that is rapidly released by biomass is approximately $80 \%$ for grasses and $90 \%$ for legumes; thus, these systems play an important role in $\mathrm{K}$ cycling.

Regarding the sowing periods, at 30,60 and 90 days, the highest $\mathrm{K}$ accumulation was observed during the first sowing period for monocropped Paiaguas palisadegrass and Paiaguas palisadegrass intercropped in rows and between rows. The higher biomass production observed in these systems during the first sowing period (COSTA et al., 2016) was most likely the predominant factor in the higher $\mathrm{K}$ accumulation and concentration in the biomass.

When evaluating the calcium concentration (Ca) at 30,60 and 90 days, during both sowing periods, the highest values were obtained in monocropped Paiaguas palisadegrass and Paiaguas palisadegrass intercropped in the rows and between rows. These results corroborate the findings regarding $\mathrm{N}$ and $\mathrm{K}$ concentrations. With respect to the sowing periods, the first period exhibited the highest calcium concentration at 30 days for monocropped Paiaguas palisadegrass, at 90 days for monocropped pearl millet and at 120 days for monocropped pearl millet and Paiaguas palisadegrass, for the row, inter-row and oversown intercrop systems, respectively.

It is important to note that after $\mathrm{K}$ and $\mathrm{N}, \mathrm{Mg}$ was the nutrient with highest concentration in the biomass. Mendonça et al. (2015) reported that approximately $70 \%$ of the $\mathrm{Mg}$ from biomass is quickly made available for the subsequent crop, as $\mathrm{Mg}$ is mostly found in the cell vacuole. The remaining $30 \%$ is a component of structural compounds in the plant and is therefore gradually and slowly released (CRUSCIOL et al. 2005).

The forage systems $(\mathrm{P}<0.05)$ affected the sulfur concentration (S) only at 120 days, with monocropped pearl millet and pearl millet intercropped in rows exhibiting the highest values (Table 6). There was no effect $(\mathrm{P}>0.05)$ of the sowing period on the $\mathrm{S}$ concentration and accumulation at all evaluations.

In contrast to $\mathrm{S}$ accumulation, monocropped Paiaguas palisadegrass exhibited the highest values,
Monocropped Paiaguas palisadegrass displayed higher $(\mathrm{P}<0.05) \quad \mathrm{Ca}$ biomass accumulation at all evaluations in both sowing periods, with values ranging from 36 to $24 \mathrm{~kg} \mathrm{ha}^{-1}$ at 30 days after the application of management procedures and $14 \mathrm{~kg} \mathrm{ha}^{-1}$ at 120 days (soybean harvest) for the first and second periods, respectively. However, according to Crusciol et al. (2005), only $30 \%$ of the $\mathrm{Ca}$ accumulated in straw is slowly released through decomposition of the remaining biomass because this nutrient is a constituent of cell structures, such as the cell wall, and is a cofactor of some enzymes related to plant respiration, which hinders its mineralization and release to the soil system. Ca residual evaluated at 120 days after the application of management procedures for a cover crop

(MENDONÇA et al., 2015) found $5 \mathrm{~kg} \mathrm{ha}^{-1}$ de Ca in a intercropped grass corn-Tanzania system. However, Costa et al. (2015) observed higher accumulation values of $32 \mathrm{~kg}$ $\mathrm{ha}^{-1}$ for millet and $12 \mathrm{~kg} \mathrm{ha}^{-1}$ for Xaraes palisadegrass during the 2009/2010 crop season. The higher values reported (COSTA et al., 2015) can be explained by biomass production, by the difference between the evaluated millet genotypes or by the fact that the crops were grown during the summer, leading to higher biomass accumulation.

Regarding sowing periods, the biomass of the Paiaguas palisadegrass monocropped and intercropped in between rows at 30 and 60 days after the application of management procedures and of the pearl millet intercropped with Paiaguas palisadegrass in between rows at 90 days exhibited the highest $\mathrm{Ca}$ accumulation during the first sowing period, which was due to the higher biomass production observed during this period (COSTA et al., 2016.

There was no significant effect $(\mathrm{P}>0.05)$ of the forage systems and sowing periods on the magnesium $(\mathrm{Mg})$ concentration, as the values observed were similar (Table $5)$. followed by the row intercrop system, the inter-row intercrop system and the monocropped pearl millet system. The oversown intercrop system was the system that least favored $\mathrm{S}$ accumulation. S exhibited the lowest accumulation in the remaining biomass among the examined nutrients. Corroborating the findings of the present study (COSTA et al., 2015) also observed that S was the nutrient showing the lowest accumulation in the remaining biomass, with values of 6 and $9 \mathrm{~kg} \mathrm{ha}^{-1}$ being observed for Xaraes palisadegrass and 17 and $11 \mathrm{~kg} \mathrm{ha}^{-1}$ for pearl millet during the 2009/2010 and 2010/2011 crop seasons, respectively.

When initial S accumulation was compared with the values obtained at 120 days after the application of management procedures, monocropped pearl millet exhibited the smallest decreases in $\mathrm{S}$ accumulation, which can be explained by the greater persistence of biomass in 
the soil due to the high carbon/nitrogen ratio (COSTA et al., 2016) and by the lignified material, which hinders the release of constituent nutrients of complex molecules present in plant tissue.

The decreasing order of nutrient accumulation in the remaining biomass under all forage systems was as follows: $\mathrm{K}>>\mathrm{Mg}>\mathrm{Ca}>\mathrm{P}>\mathrm{S}$. These results highlight the importance of pearl millet Paiaguas palisadegrass intercropping in production systems, as these species are involved in nutrient cycling. Additionally, the remaining biomass in the soil promotes maintenance and protection of the soil-plant system, providing benefits to the soil microbiota via the nutrient supply and maintaining adequate moisture content for the subsequent crop (KLIEMANN et al., 2006).

Therefore, it is important that species that produce biomass with slower decomposition be chosen (TORRES et al. 2005). Thus, tropical forages intercropped with annual crops can lead to permanent soil cover under a no-tillage system (PARIZ et al., 2011). However, it should be noted that the process of nutrient cycling requires time for these and other nutrients to be made available to the soil. Thus, the benefits are not immediately observed (COSTA et al., 2012).

Therefore, the pearl millet Paiaguas palisadegrass intercrop system is a good alternative, involving quality biomass produced in crop-livestock integration system that operates in the cycling of nutrients for direct sowing. Additionally, it maintains the stock of carbon in biomass and soil (COSTA et al., 2016), is considered a soil management mitigating the greenhouse effect and preserving the environment.

\section{CONCLUSIONS}

Monocropped Paiaguas palisadegrass and Paiaguas palisadegrass intercropped in rows and between rows exhibited higher nutrient cycling and accumulation in the remaining biomass.

The decreasing order of nutrient accumulation the under all of the examined forage systems was as follows: $\mathrm{K}>\mathrm{N}>\mathrm{Mg}>\mathrm{Ca}>\mathrm{P}>\mathrm{S}$. Potassium was the most accumulated nutrient in the biomass and exhibited the greatest percent decrease with the decomposition time.

The first sowing period of the forage systems led to higher nutrient cycling and accumulation in the biomass.

Intercropped systems through in integrated croplivestock showed a promising cultivation technique to maintain the nutrient cycling and accumulation with sustainability.

\section{REFERENCES}

ASSMANN, A.L.; SOARES, A.B.; ASSMANN, T.S. Integração Lavoura-Pecuária para a Agricultura Familiar. Londrina: Instituto Agronômico do Paraná, 2008. 49 p.

BERNARDES G.T.; SILVEIRA, P.M. MESQUITA, M.A.M.; AGUIAR, R.A.; MESQUITA, G.M. Decomposição da biomassa e liberação de nutrientes dos capins Braquiária e Mombaça, em condições de Cerrado. Pesquisa Agropecuária Tropical, v. 40, n. 3, p. 370-377, jul/set 2010

COSTA, N.R.; ANDREOTTI, M.; GAMEIRO, R.A.; PARIZ, C.M.; BUZETTI, S.; LOPES, K.S.M. Adubação nitrogenada no consórcio de milho com duas espécies de braquiária em sistema plantio direto. Pesquisa Agropecuária Brasileira, v. 47, n. 8, p. 1038-1047, ago. 2012.

COSTA, N.R.; ANDREOTTI, M.; ULIAN, N.A.; COSTA, B.S.; PARIZ, C.M.; TEIXEIRA FILHO, M.C.M. Acúmulo de nutrientes e tempo de decomposição da palhada de espécies forrageiras em função de épocas de semeadura. Bioscience Journal, v.31, p.818-829, mai. 2015.

COSTA, R.R.G.F.; COSTA, K.A.P.; ASSIS, R.L.; SANTOS, C.B.; SEVERIANO, E. C.; ROCHA, A.F.S. ; OLIVEIRA, I.P.; Costa. P.H.C.P.; SOUZA, W.F.; AQUINO, M. M. Dynamics of biomass of pearl millet and Paiaguas palisadegrass in different forage systems and sowing periods in yield of soybean. African Journal of Agricultural Research, v. 11, p. 4661-4673, nov. 2016.

CRUSCIOL, C.A.C.; COTTICA, R.L.; LIMA, E.V.; ANDREOTTI, M.; MORO, E.; MARCON, E. Persistência de palhada e liberação de nutrientes do nabo forrageiro no plantio direto. Pesquisa Agropecuária Brasileira, v.40, n.2 p.161-168, fev. 2005.

EMBRAPA SOLOS - EMPRESA BRASILEIRA DE PESQUISA AGROPECUÁRIA -EMBRAPA. Centro Nacional de Pesquisa de Solos. Sistema Brasileiro de Classificação de Solos. Embrapa CNPS, 3 ed. Rio de Janeiro, 2013. 353p.

FERREIRA, D.F. Sisvar: a computer statistical analysis system. Ciência e Agrotecnologia, v. 35, p.1039-1042, 2011.

FERREIRA, E.V.O.; ANGHINONI, I.ANDRIGHETTI, M.H.; MERTINS A. P.; CARVALHO P. C. F. Ciclagem e balanço de potássio e produtividade de soja na integraçãolavoura-pecuária sob semeadura direta. Revista Brasileira de Ciência do Solo, v.35, p.161-169, fev. 2011. 
KLIEMANN, H.J.; BRAZ, A.J.B.P.; SILVEIRA, P.M. Taxa de composição de resíduos de espécies de cobertura em Latossolo Vermelho Distroférrico. Pesquisa Agropecuária Tropical, v. 36, n. 1, p. 21-28, jan/abr. 2006.

MACEDO, M.C.M. Integração lavoura e pecuária: o estado da arte e inovações tecnológicas. Revista Brasileira de Zootecnia, v. 38, p. 133-146, jul.2009.

MALAVOLTA, E.; VITTI, G.C.; OLIVEIRA, S.A. Avaliação do estado nutricional de plantas: princípios e aplicações. 2.ed. Piracicaba:Potafos, 1997. 319p.

MENDONÇA, V.Z.; MELLO, L.M.M.; ANDREOTTI, M.; PARIZ, M.C.; YANO, E.H.; PEREIRA, F.C.B.L. Liberação de nutrientes da palhada de forrageiras consorciadas com milho e sucessão com soja. Revista Brasileira de Ciência do Solo, v.39, p.183-193, mai/jun. 2015.

NUNES, A. S. TIMOSSI, P.C; PAVANI, M.C.M.O.D; COSTA ALVES, A.P.L. Formação de cobertura vegetal e manejo de plantas daninhas na cultura da soja em sistema plantio direto. Planta Daninha, v. 28, n. 4, p. 727-733, dez. 2010 .

PACHECO, L.P.; PIRES, F.R.; MONTEIRO, F.P.; PROCOPIO, S.O.; ASSIS, R.L.; CARMO, M.L.; PETTER, F.A. Desempenho de plantas de cobertura em sobressemeadura na cultura da soja. Pesquisa Agropecuária Brasileira, v. 43, p.815-823, jul. 2008.

PARIZ, C.M.; ANDREOTTI, M.; BUZETTI, S.; BERGAMASCHINE, F.A.; ULIAN, N.A.; FURLAN, L. C.; MEIRELlES, P. R. L.; CAVASANO, F. A. Straw decomposition of nitrogen-fertilized grasses intercropped with irrigated maize in an integrated crop livestock system. Revista Brasileira de Ciência do Solo, v. 35, p. 2029-2037, dez. 2011.
ROSOLEM, C.A.; CALONEGO, J.C.; FOLONI, J.S.S. Lixiviação de potássio da palha de espécies de cobertura de solo de acordo com a quantidade de chuva aplicada. Revista Brasileira de Ciência do Solo, v. 27, p. 355-362, abr.2003.

SANTOS, F.C.; NEVES, J.C.L.; NOVAIS, R.F.; ALVAREZ V., V.H.; SEDIYAMA, C.S. Modelagem da recomendação de corretivos e fertilizantes para a cultura da soja. Revista Brasileira de Ciência do Solo, v.32, p.1661-1674, ago. 2008.

THOMAS, R.J.; ASAKAWA, N. M. Decomposition of leaf litter tropical forage grasses and legumes. Soil Biology and Biochemistry, v.25, p.1351-1361,out. 1993.

TORRES, J.L.R.; PEREIRA, M.G.; ANDRIOLI, I.; POLIDORO, J.C.; FABIAN, A.J. Decomposição e liberação de nitrogênio de resíduos culturais de plantas de cobertura em um solo de Cerrado. Revista Brasileira de Ciência do Solo, v. 29. p.609-618, jul. 2005.

TORRES, J.L.R.; PEREIRA, M.G.; FABIAN, A.J. Produção de fitomassa por plantas de cobertura e mineralização de seus resíduos em plantio direto. Pesquisa Agropecuária Brasileira, v.43, n.3, p.421-428, mar. 2008.

TORRES, J.L.R.; PEREIRA, M.G. Dinâmica do potássio nos resíduos vegetais de plantas de cobertura no cerrado. Revista Brasileira Ciência Solo, v.32, p.1609-1618, ago. 2008.

XAVIER, D. F.; LÉDO, F. J. S.; PACIULLO, D. S. C.; URQUIAGA, S.; ALAVES,B. J. R. and BODDEY, R. M. 2014. Nitrogen cycling in a Brachiaria based silvopastoral system in the Atlantic forest region of Minas Gerais, Brazil. Nutrient Cycling in Agroecosystems.V.99, P.45-62, jul. 2014. 